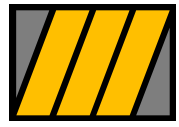

ESCUELA DE NEGOCIOS Universidad Torcuato Di Tella

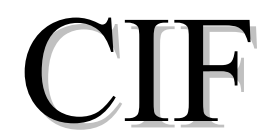

Centro de Investigación en Finanzas

Documento de Trabajo 04/2005

\title{
Managing Systemic Liquidity Risk in Financially Dollarized Economies
}

\author{
Alain Ize \\ $I M F$ \\ Miguel A. Kiguel \\ UTDT \\ and \\ Eduardo Levy Yeyati \\ UTDT and IADB
}
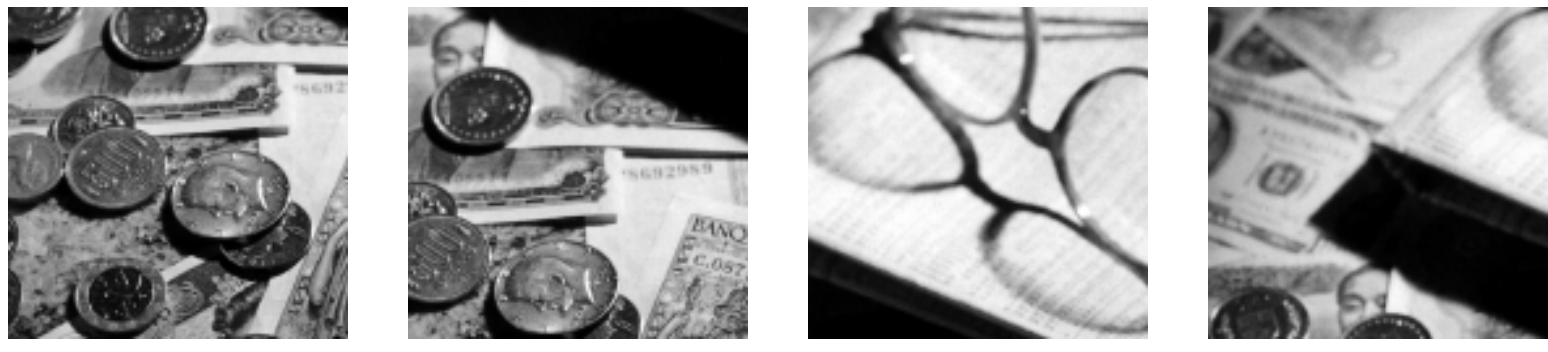

Almirante Sáenz Valiente 1010 C1428BIJ Buenos Aires • Tel: (54 11) 4783.3112

Fax: (54 11) 4783.3220 - Web site: www.utdt.edu/departamentos/empresarial/cif/cif.htm 


\title{
IMF Working Paper
}

Monetary and Financial Systems Department

\section{Managing Systemic Liquidity Risk in Financially Dollarized Economy}

\author{
Prepared by Alain Ize, Miguel A. Kiguel, and Eduardo Levy Yeyati ${ }^{1}$
}

August 2005

\begin{abstract}
This Working Paper should not be reported as representing the views of the IMF.

The views expressed in this Working Paper are those of the author(s) and do not necessarily represent those of the IMF or IMF policy. Working Papers describe research in progress by the author(s) and are published to elicit comments and to further debate.

This paper evaluates ways to protect highly dollarized banking systems from systemic liquidity runs (such as the ones that took place recently in Argentina, Uruguay, and Paraguay). In view of the limitations of available (private or official) insurance schemes, and the distortions introduced by central bank lending of last resort (LOLR), the authors favor decentralized liquid foreign asset requirements on dollar deposits, supplemented by a scheme of "circuit breakers." The latter combines the use of limited dollar liquidity to ensure the convertibility of transactional deposits with a mechanism that automatically limits the convertibility of dollar term deposits once triggered by a predetermined decline in banks' liquidity.
\end{abstract}

JEL Classification Numbers: E58, G21, G33

Keywords: Dollarization, Systemic Liquidity, Banking Crises

Authors’E-Mail Addresses: aize@imf.org, kiguel@gmail.com, ely@utdt.edu

\footnotetext{
${ }^{1}$ Miguel Kiguel, Private Consultant; Eduardo Levy Yeyati, Universidad Torcuato di Tella, Argentina. An earlier version of this paper was presented at a Conference on the Policy Implications of De Facto Dollarization, held in Lima, during April 21-22, 2005. The authors would like to thank Julio de Brun, Philip Turner, and other participants in the conference for their comments.
} 


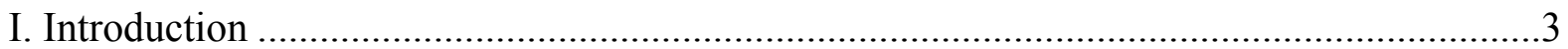

II. Can Liquidity Be Borrowed? .....................................................................................

A. Self-Insurance versus External Insurance ...................................................

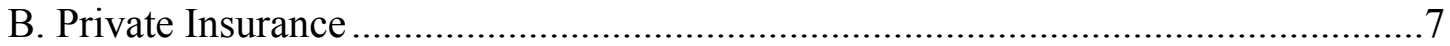

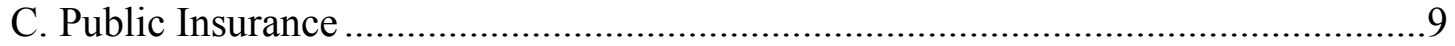

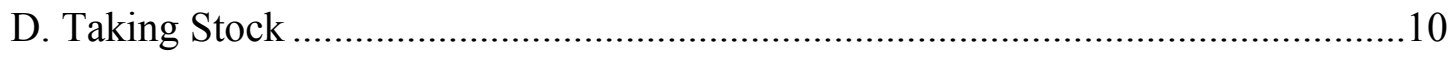

III. The Case for Liquidity Requirements................................................................... 10

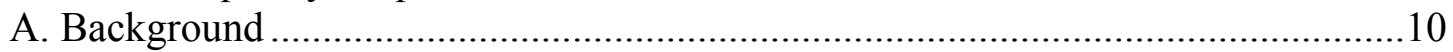

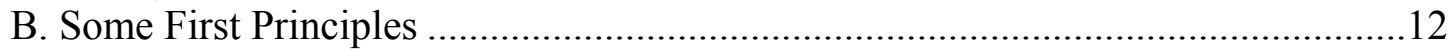

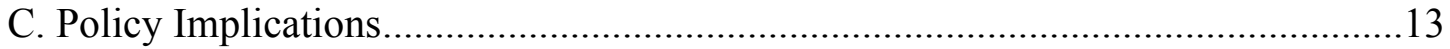

IV. Should Circuit Breakers Be Institutionalized? .......................................................... 15

A. Why Circuit Breakers?.................................................................................... 15

B. Which Deposits Should Be Subjected to the CBR? ......................................... 17

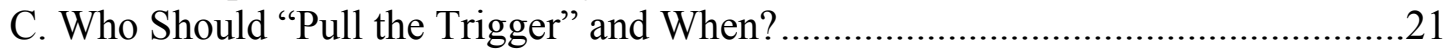

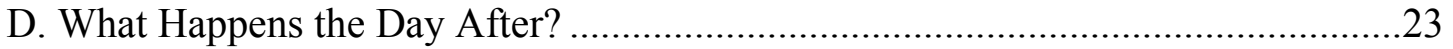

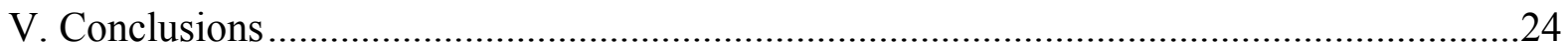

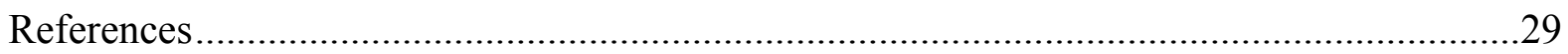

Table

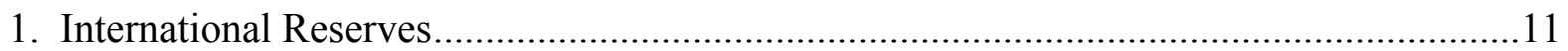

Boxes

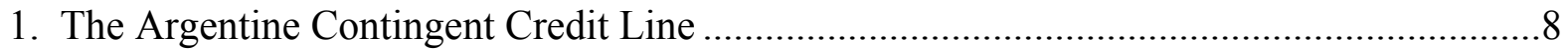

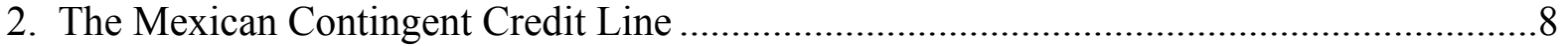

3. Introducing CBR-Type Measures Under Crises .........................................................16

4. CBR and Suspension of Convertibility in the Free Banking Era....................................18

5. A More Recent Example of Pre-Programmed CBR: The Chilean

"Narrow Bank" Safety Net.

Appendix

I. A Model of Lender of Last Resort (LOLR) and Bank Demand

for Dollar Liquidity

Appendix Figure

1. Liquidity Premium 


\section{INTRODUCTION}

Dollarized economies have experienced in recent years a number of severe banking and currency crises in which runs on bank deposits, mainly dollar deposits, have played a major role. ${ }^{2}$ The recent Argentinean currency and financial crisis and its tidal waves throughout the region, notably in Uruguay and Paraguay, has brought home the realization that dollarization can greatly complicate crisis management and create major financial vulnerabilities. ${ }^{3}$

While the issue of ascertaining whether these crises were self-fulfilling or driven by deteriorating fundamentals is outside the scope of this paper, it is clear that systemic runs in dollarized economies have an important self-fulfilling component. ${ }^{4}$ On the one hand, dollar deposits can only be paid off to the extent banks have sufficient dollar liquidity or sufficient access (through lender of last resort, or LOLR, arrangements) to dollar liquidity on-lent by the central bank. In a highly dollarized fractional reserve banking system, only a limited proportion of bank deposits can be backed this way. At the same time, many factors exacerbate the run, once it is under way. In addition to incurring potential losses through the firesale of bank assets, depositors that are left in the banks face the threat of last resort measures designed to stop the run, including deposit freezes.

The rationale for running is even more compelling in a mixed-currency economy than in a peso economy or a fully dollarized economy, as threats loom of forced conversions into pesos, large exchange rate depreciations, or some combination of the two (as in the midst of the Argentine crisis of 2002). The exchange rate is typically floated to stem runs on peso deposits - including after a forced conversion that broadens the peso deposit base - or to limit the loss of international reserves - including after banks are given LOLR support in pesos to meet dollar deposit withdrawals. While freeing the exchange rate can be a lifeline for the pesos (the resulting overshooting helps maintain them within the economy, if not

\footnotetext{
${ }^{2}$ While recent deposit runs in highly dollarized countries have affected both peso and dollar deposits, the magnitude of dollar runs was substantially larger (both in absolute magnitude and as a proportion of initial deposits), reflecting in part the fact that peso deposits are largely transactional (see Gulde et al., 2004, and Ingves and Moretti, 2003).

${ }^{3}$ Such events are scarcely new. The Argentine crisis was itself to a large extent a repeat of the much earlier but quite similar "mex-dollar" crisis in Mexico (see Ize and Ortiz, 1986).

${ }^{4}$ The notion that self-fulfilling liquidity runs are the main drivers of systemic financial crises has gained advocates in academic and policy quarters. According to this view, increases in perceived rollover risk that trigger interest rate hikes or outright rationing in capital markets may precipitate a default - even in the absence of solvency problems. This multipleequilibrium argument, rooted in Diamond and Dybvig's (1983) model of self-fulfilling bank runs, has been highlighted for the case of sovereign debt by Calvo (1988) and, more recently, Cole and Kehoe (1998).
} 
within the banking system), it can be the "nail in the coffin" for the dollars. ${ }^{5}$ Indeed, it is likely to further deteriorate the quality of dollar loans, thereby worsening banks' financial position and amplifying potential losses to depositors. ${ }^{6}$ Expectations of such events therefore add fuel to the run, both on pesos and dollars, and enhance the probability that they will actually materialize.

This paper deals with three basic issues at the core of systemic liquidity risk management in dollarized economies. First, in the absence of better alternatives, supervisory authorities in most financially dollarized countries have shown a distinct preference for dollar liquidity, in the form of a large stock of international reserves and/or substantial liquid foreign asset requirements (LARs) on dollar deposits. However, large liquidity buffers are expensive in countries where country risk premia are high (which is typically the case in highly dollarized countries). Thus, most observers would agree that some form of insurance arrangement, such that commercial banks (or the central bank) can obtain automatic access to an external credit line in times of need, should in principle be welfare improving. However, the experience thus far with such arrangements has not been very successful. The paper discusses why and argues that the difficulties met so far are unlikely to go away in the foreseeable future.

Second, the paper discusses whether the liquidity buffer should be held in a centralized or decentralized manner, a question that has been barely addressed in the literature. With the help of a stylized example, we show that, in the absence of LARs, centralizing reserves at the central bank introduces an agency cost leading to suboptimal dollar liquidity holdings and an implicit subsidy to dollar intermediation. By contrast, decentralized holdings (through the imposition of LARs) help internalize the externalities of currency risk, at the cost of forgoing the potential diversification benefits of a common liquidity fund. In the context of largely systemic shocks, we conclude that the cost of the latter strategy is outweighed by its benefits: a positive LAR (and one greater than the one corresponding to peso deposits) is indeed optimal from a prudential perspective. However, we also argue that, once LARs have been introduced, it can make sense to put in place a limited dollar liquidity recycling facility designed to address idiosyncratic liquidity risk and further increase the resilience of the banking system.

Unless LARs are set at an extremely high level, resulting in a prohibitive cost, there will always be a remnant probability that the run will exhaust the available liquidity. ${ }^{7}$ The

${ }^{5}$ The link between currency and banking crises has been analyzed, among many others, by Goldfajn and Valdés (1997) and Chang and Velasco (1998), and documented empirically by Kaminski and Reinhart (2002).

${ }^{6}$ See Levy Yeyati, Martínez Pería, and Schmukler (2004).

${ }^{7}$ Indeed, the very presence of dollar liquidity in the banking sector may fuel the run, much in the same way stressed by Zettelmeyer (2000) for capital outflows in the presence of (inadequately small) international rescue packages. 
question then is whether there are ways to economize on the use of reserves and stop the run in ways that are less traumatic than the last-resort measures cited above. The last section of the paper proposes a scheme that supplements the LAR with the concept of "circuit breaker" (CBR), i.e., a temporary, efficient, and pre-programmed suspension of convertibility. The proposal combines the use of limited dollar liquidity earmarked to ensure the full convertibility of transactional dollar deposits with a mechanism that automatically reprograms dollar-term deposits once triggered by a sufficient decline in banks' liquidity. We conclude that the CBR, if well designed and accompanied by adequate prudential policies (including as regards bank resolution), could both limit the need for (hence the cost of) a dollar liquidity buffer and narrow the scope for destabilizing runs on the banking system. We also suggest that a system with CBR-like properties could be de facto introduced without actually referring explicitly in the legal framework to the possible need for restructuring bank deposits in the event of systemic crises.

Section II reviews recent experiences with liquidity insurance. Section III argues in favor of LARs. Section IV presents the case for circuit breakers. Section V concludes.

\section{CAN LIQUidity BE BorRoWed?}

\section{A. Self-Insurance versus External Insurance}

There are two ways in which a dollarized financial system can insure itself against a dollar liquidity shortage:

- Self-insurance, through the holding of a substantial stock of foreign-currencydenominated liquid assets, either by the central bank, or by individual banks.

- External insurance, through a contract with private providers of dollar liquidity (typically, a consortium of financial institutions) or, alternatively, with international financial institutions (IFIs) that ensures financial institutions access to dollar liquidity at a reasonable cost. ${ }^{8}$

Whether the liquidity buffer is held by the central bank or by commercial banks, selfinsurance entails a non-trivial cost (namely, the cost that the government or the financial institutions have to pay in excess of the return on liquid foreign assets to finance the purchase of the reserves), which combines a maturity and a sovereign risk premia. A back-of-theenvelope calculation would estimate this cost as the difference between the average yield of

\footnotetext{
${ }^{8}$ The concept has obvious similarities with the definition of a standard insurance contract, under which the insurer promises to transfer to the insured party, contingent on the realization of a well-defined event, a pre-specified amount, typically proportional with the losses associated with the event. Indeed, liquidity insurance can be understood as interest rate insurance, whereby the insurer promises to lend at a pre-specified rate.
} 
external debt (as measured, e.g., by J.P. Morgan's EMBI index) and the return on central bank reserves, a non-negligible number for most emerging economies. ${ }^{9}$

Should liquidity runs be purely self-fulfilling, an external insurance would thus clearly be less expensive than holding the liquidity. Indeed, as the literature on bank runs clearly illustrates, the likelihood of a self-fulfilling run is endogenous to the presence (and amount) of insurance: ultimately, a perfectly insured country should be immune to a non-fundamental liquidity run. Thus, an external insurer facing zero risk could offer full insurance (namely, a contract providing the threshold level of reserves as needed) at zero cost. ${ }^{10}$

In practice, however, things are more complicated. First, the size of the insurance package that would be needed to fully insure a banking system (e.g., to fully insure against selffulfilling runs and eliminate risk) is typically quite large, and the risk associated with it difficult to diversify. Second, and perhaps more important, since liquidity insurance is based on a loan rather than a straight transfer (where no repayment is expected from the insured party), the solvency of the insured party is a precondition for the sustainability of the scheme. Yet, runs are often driven by fundamentals, hence accompanied by expectations of losses. Third, the fact that the insurable event (e.g., a liquidity run) and the associated losses (e.g., the decline in the value of the banks' assets) are hard to define in a verifiable way, provides fertile grounds for moral hazard.

Thus, insurance premia are likely to be prohibitively expensive unless the facility is collateralized. ${ }^{11}$ However, the availability of collateral in the case of emerging economies is

\footnotetext{
${ }^{9}$ The country risk premium may overstate the marginal borrowing cost, to the extent that reserve holdings contribute to lowering the sovereign risk premium paid on the full stock of debt. However, country risk may also understate the marginal cost if the country faces an upward-sloping supply of funds. Ultimately, the effect of netting out debt and reserves (for example, through a debt buyback) will likely depend on the liquidity needs of the country and cannot be signed unambiguously.
}

10 The argument is made by Cordella and Levy Yeyati (2005) to propose that IFIs provide an uncontingent country insurance facility to cope with non-fundamental, self-fulfilling liquidity runs. It has to be noted, however, that if all risk were non-fundamental, a sufficiently large stock of reserves would eliminate the sovereign risk premium, reducing the cost of carrying reserves to the maturity premium.

${ }^{11}$ In most private insurance contracts, the insurer charges up front a premium proportional to the expected transfer. Similarly, a liquidity insurance contract would require a premium to compensate the insurer for the lower rate charged in case the policy is activated - and a commitment fee would be charged to compensate the insurer for the liquidity premium associated with the provision of funds on short notice. This premium would typically be minor, particularly in the case of a pure liquidity run where the repayment capacity of the 
generally limited and of dubious collateral value. Faced with poor collateral, insurers are thus likely to use any means they have to limit their downside exposure as the level of risk rises, thereby limiting the benefits of the insurance. Indeed, this is what happened in the two recent examples of large private insurance arrangements.

\section{B. Private Insurance}

The closest recent experiment of privately funded liquidity insurance was the contingent credit line subscribed between the Argentine central bank and a consortium of foreign banks in the late 1990s, whereby the central bank — as well as participating local banks - had the option to engage in a repurchase agreement against Argentine sovereign securities for up to US\$6.7 billion (see Box 1). However, the coverage of this contract was relatively limited; its execution was delayed until August 2001, when the liquidity run was well underway; and it was executed only in connection with an agreement with the IMF that prompted up the price of bonds, albeit momentarily. All in all, the contract ultimately provided a meager US $\$ 1.77$ billion (out of US\$4.75 billion available at the beginning of 2001). Moreover, due to the ongoing liquidity run, the decline in the price of the bonds used as collateral implied a reduction in the size of the line, which dropped to US\$1.35 billion at the first three-month renewal, thus generating a financing gap for the difference-exactly the opposite effect as the one that motivated the contract in the first place. ${ }^{12}$

A second related experience with this type of private liquidity insurance contract is provided by Mexico (see Box 2). The line was withdrawn in its entirety by the Mexican government on September 30,1998, prompted by a deterioration of access to the international capital markets coupled with a decline in oil prices that reduced fiscal resources. However, as was to be the case later on in Argentina, insuring banks contested the decision of the government to use these resources, on grounds that current external conditions did not warrant the execution of the contract. Although they finally conceded to extend the loan, they subsequently refused

insured party is not at stake. However, liquidity and solvency risk are difficult to disentangle, complicating the computation of a fair premium.

12 Many reasons prevented the issuance of additional collateral at the time. Besides budgetary constraints on the amount of debt to be issued, there were legal restrictions as the covenants stated in some detail the bonds that could be included in the deal, and many of those could not be reopened. More important, issuing bonds in private markets was not an option in the middle of the run - the very reason why liquidity insurance was needed. One alternative would have been to endow the central bank with additional bonds at the time of negotiating the agreement with the banks. 


\section{Box 1. The Argentine Contingent Credit Line}

Under this contract, the central bank was allowed to withdraw, in the event of a crisis, from a credit line in exchange for dollar-denominated government bonds. The maturity of the contract was three years, with an ever-greening clause such that, every three months, the life of the program was extended a further three months (the high frequency of this revision clause, while it helped to reduce the commitment fee, ultimately proved to be a severe drawback of the scheme). Argentine dollar-denominated bonds were taken at 80 percent of their market value (if the price of the bonds fell by more than 5 percent, further bonds had to be delivered as margin).

The contract stipulated an annual commitment fee of 32 basis points (bps), plus an interest rate on withdrawn funds of roughly LIBOR plus 205 basis points. The insurance cost was certainly small compared to that of holding reserves (for illustrative purposes, the average government bond yield in 1998, by the time the contract was in place, was around 940 bps). Using the spread over the average return on reserves reported by the central bank for the same year as a proxy for the cost of carry of additional reserves, increasing the stock by the amount committed under the contract would have entailed a "fee" cost of about 570 bps (alternatively, a flow cost of roughly US $\$ 380$ million per year), well above the 32 bps commitment fee under the contract.

\section{Box 2. The Mexican Contingent Credit Line}

In November 1997, the Mexican government subscribed a contingent credit line with 31 major private international financial institutions, at the time when the contagion effects from the Asian crises started to be felt in emerging markets. The facility would provide the government with sufficient resources to meet the external debt service in the event of a closure of the country's access to international capital markets. Specifically, it made available US $\$ 2.5$ billion (later extended to US $\$ 2.66$ billion with the addition of two new institutions) for up to 18 months, at a rate equal to $3 \mathrm{M}$ LIBOR plus $50 \mathrm{bps}$ during the first semester (increasing by 25 bps each subsequent semester), at the cost of an annual commitment fee of $30 \mathrm{bps}$ (or, approximately, US\$7.6 million).

to renew the contract. While it is difficult to attribute this controversy to one single cause, a balanced judgment would point to a combination of two factors: the difficulty in defining unambiguously the event that triggers the contingency clause, and the reluctance of the insurer to assume the costs of the contract. At any rate, the contract proved to be subject to controversial interpretations that may detract from its timeliness and effectiveness. Thus, the appeal of this type of solution appears to be (as it was in the Argentine case) subject to important caveats. The first one is related to the fact that, in this case, the insurer 
actually has a stake in the value of the country and might want to hedge part of this risk. More precisely, insurer banks, faced with a mounting probability of a crisis that triggers the insurance policy, may have incentives to hedge their growing exposure by shorting the country's assets, accelerating the collapse. The same is valid if liquidity insurance is triggered by a currency run: growing exchange rate pressure would lead insurers to short the domestic currency, deepening the currency crisis. ${ }^{13}$

The second shortcoming is associated with size. If this type of contracts extends to several emerging markets, the scope for the insurer to diversify risks than are highly correlated within the region narrows, hence limiting the size of the coverage. Thus, inasmuch as currency attacks have a common pattern across insured countries, there will be a limit to the coverage that private international institutions may be willing to extend.

The third obstacle to private insurance is the flipside of the previous one, namely, the risk that insurers, lured by juicy commissions, take on more risk than they can reasonably handle. Note that this could lead to what amounts to a reverse moral hazard problem, as banks may become reluctant to provide the committed resources once the crisis is underway.

In sum, these two experiences seem to indicate that private insurance, while possibly useful as a partial complement to other mechanisms, is not a promising alternative for countrywide coverage of systemic liquidity risk.

\section{Public Insurance}

Some of the main drawbacks of private insurance (particularly moral hazard and the need for hedging) can be overcome by contracting insurance from nonprofit official organizations (such as IFIs) or other regional financial arrangements (such as the Asian Chiang Mai initiative). In the case of the IMF, while this is an issue that goes much beyond the scope of this paper, it will suffice here to note that IMF-led packages have so far provided liquidity insurance only imperfectly and reluctantly, and with the broader objective of stabilizing the capital account, which goes beyond the more specific one of assisting local banks. Moreover, difficulties in isolating liquidity from solvency concerns have hampered the scope for a smooth and timely provision of liquidity support. Thus, the recent IMF's contingent credit line (CCL) initiative, the closest to a liquidity insurance scheme ever launched by an IFI, required a somewhat discretionary pre-qualification process at the request of the countries. Combined with its limited size, this reduced its potential attractiveness. As a result, it was never requested and was ultimately phased out.

\footnotetext{
${ }^{13}$ On this, see Broda and Levy Yeyati (2003a). Note that individual institutions, by hedging, would increase their exposure through the insurance policy. However, they are likely to do so to the extent that the negative impact of reducing their position on the country is diluted in the aggregate, while the benefits of hedging accrue entirely to them. In addition, the margin call should also add to this negative feedback effect.
} 


\section{Taking Stock}

Some preliminary conclusions can be drawn from this brief overview. First, it is clear that private liquidity insurance is bound to be limited and, possibly, unreliable in the event of a substantive shock, both because of the capacity of the insurer to transfer back the risk to the insured party, and because the limited scope for diversification of country risk may compromise the profitability and solvency of the insurer as the size of the contract increases. ${ }^{14}$ Second, while the role of IFIs as country insurers certainly deserves rigorous consideration, it is realistic to assume that no ad hoc country insurance facility will be launched in the near future.

This leaves the country with the self-insurance option as the more realistic and reliable (albeit costly) option. In the case of a liquidity run on the banking sector, this option can take essentially two forms: liquid assets requirements (LARs) on dollar deposits, or the accumulation of central bank reserves. To the analysis of these options we now turn.

\section{The CASE FOR LIQUIDITY REQUIREMENTS}

\section{A. Background}

Reflecting the difficulties of contracting external insurance, most financially dollarized economies - particularly those hit by recent currency runs-have exhibited a preference for self-insuring through large international reserve buffers. This has been the case, irrespective of the exchange regime (see Table 1$).^{15}$

The accumulation of international liquidity can take different forms, however, depending on who is the owner of the liquidity. In the traditional (and most frequently encountered) form, the central bank centralizes most of this liquidity by subjecting commercial banks to reserve requirements or by borrowing in the domestic debt market. It administers its use by providing

${ }^{14}$ There have also been recent proposals to use non-emerging market specific assets, such as options on the S\&P volatility index, as a hedge against sudden stop-induced liquidity crises (see Caballero and Panageas, 2005). However, it is questionable whether the depth of such markets is sufficient to provide broad-based insurance at accessible prices. Moreover, even if there is a broad correlation between world volatility indices and the probability of bank runs in emerging countries, the timeliness of the hedge (a crucial condition for its effectiveness) cannot be ensured.

${ }^{15}$ Emerging economies are defined as those included in JP Morgan's EMBI GLOBAL portfolio. Interestingly, the tendency to increase the stock of reserves applies also to economies with non-dollarized banking sectors (e.g., South East Asian countries), as they still have a sizable stock of foreign currency liabilities that may impinge on the repayment capacity of the public or corporate sector in the event of a sudden devaluation. 
Table 1. International Reserves (As percentage of GDP)

\begin{tabular}{|c|c|c|}
\hline Country & 1992 & 2002 \\
\hline Algeria & 3.0 & 41.3 \\
\hline Argentina & 4.2 & 10.2 \\
\hline Brazil & 5.8 & 8.1 \\
\hline Bulgaria & 10.3 & 27.9 \\
\hline Chile & 19.8 & 22.0 \\
\hline China,P.R.: Mainland & 4.0 & 22.5 \\
\hline Colombia & 13.2 & 12.7 \\
\hline Costa Rica & 11.7 & 8.7 \\
\hline Côte d'Ivoire & 0.1 & 15.9 \\
\hline Croatia & 1.7 & 25.8 \\
\hline Ecuador & 6.6 & 2.8 \\
\hline Egypt & 25.4 & 15.4 \\
\hline Hungary & 11.6 & 15.0 \\
\hline India & 2.0 & 13.5 \\
\hline Indonesia & 7.3 & 17.7 \\
\hline Israel & 7.7 & 22.8 \\
\hline Jordan & 14.6 & 42.4 \\
\hline Korea & 5.0 & 22.1 \\
\hline Lebanon & 26.3 & 41.6 \\
\hline Malaysia & 28.4 & 35.0 \\
\hline Mexico & 5.1 & 7.7 \\
\hline Morocco & 12.2 & 27.5 \\
\hline Nigeria & 3.4 & 15.9 \\
\hline Pakistan & 1.7 & 12.6 \\
\hline Panama & 7.3 & 9.5 \\
\hline Peru & 7.8 & 16.6 \\
\hline Philippines & 8.1 & 17.2 \\
\hline Poland & 4.6 & 14.6 \\
\hline Russia & n.a. & 12.7 \\
\hline South Africa & 0.8 & 5.3 \\
\hline Thailand & 18.3 & 30.0 \\
\hline Turkey & 3.7 & 14.5 \\
\hline Ukraine & 2.3 & 9.9 \\
\hline Uruguay & 3.8 & 6.2 \\
\hline Venezuela, Rep. Bol. & 15.4 & 8.5 \\
\hline Average EM & 8.9 & 18.1 \\
\hline Australia & 3.5 & 4.7 \\
\hline Canada & 1.6 & 4.4 \\
\hline New Zealand & 7.3 & 5.5 \\
\hline Norway & 8.7 & 16.1 \\
\hline Switzerland & 13.0 & 13.9 \\
\hline United Kingdom & 3.2 & 2.1 \\
\hline United States & 0.6 & 0.3 \\
\hline Average Industrials & 5.4 & 6.7 \\
\hline
\end{tabular}

Sources: Reproduced from Cordella and Levy Yeyati (2005). 
LOLR in domestic currency and intervening in the foreign exchange market to sterilize the excess liquidity, or by providing LOLR directly in foreign currency to banks incurring dollar deposit outflows. ${ }^{16}$ However, the need to fend off pressures to use this stock of liquidity for non-intended purposes has motivated in many countries the introduction of liquid assets requirement (LARs) on financial institutions (as in Argentina under the currency board). In such cases, the contingency fund is raised and directly invested by the banks in a foreign account.

\section{B. Some First Principles}

The model presented in Appendix I discusses the comparative benefits of either approach, illustrating two main, rather intuitive aspects.

The first one highlights the fact that access to a LOLR facility, whether in pesos or in dollars, is a substitute for the banks' own liquidity holdings, thereby reducing banks' demand for precautionary liquidity. In the absence of LOLR, banks demand liquid reserves up to the point where the marginal carrying cost of the reserves equals the marginal cost of falling short of reserves, times the probability of facing such a shortage. By contrast, with a LOLR, banks restrict their demand such that the marginal carrying cost of the reserves equals the marginal cost of borrowing from the LOLR facility, times the probability of falling short. Since in the relevant case, the cost of borrowing must be below the cost of falling short, it follows that banks demand less reserves in the presence of a LOLR ${ }^{17}$ Specifically, they restrict the use of their own reserves to the smaller, most likely shocks, and rely on the central bank's LOLR to cover the larger, less likely shocks.

The second aspect stressed by the model is the fundamental asymmetry regarding the cost to the central bank of providing a peso LOLR versus a dollar LOLR. In the first case, the LOLR can be offered at virtually no cost through the issuance of peso monetary liabilities. Indeed, even if the provision of liquidity is fully sterilized, the risk-adjusted rate it receives on its loans would be typically higher than the rate it pays on its bonds, so that a peso LOLR could be regarded as a profitable activity. More important, it is also socially desirable because it makes banks more resilient to runs, hence less exposed to costly liquidations. ${ }^{18}$ Instead, a

${ }^{16}$ A minor variation on the same idea is a fiscally budgeted contingency fund (as in Hong Kong) by which the government (as opposed to the central bank) can act as a lender of last resort.

${ }^{17}$ Note that, if the borrowing cost exceeds the cost of the shortage (associated, e.g., to the fire sale of assets), banks would never use the LOLR facility, which would therefore become irrelevant.

18 The central bank intermediates between depositors and banks following a general loss of confidence in the same way it steps into the interbank market to intermediate between banks 
peso central bank can only provide dollar LOLR to the extent that it holds dollar reserves. However, the carrying cost of dollar reserves exceeds the expected revenue from their use in LOLR. Indeed, should this not be the case, commercial banks would be better off holding their own reserves rather than borrowing them (at a penalty rate) from the central bank. Thus, a dollar LOLR is costly to a central bank. ${ }^{19}$ At the same time, what constitutes a cost to the central bank becomes a subsidy for commercial banks - at the expense of the representative taxpayer. Thus, the dollar LOLR limits the risk of dollar deposits and lowers their cost, thereby promoting excessive dollar intermediation.

A corollary of the model is that, in much the same way as any other unfairly priced insurance scheme, the dollar LOLR facility subsidizes - in addition to currency risk - risk-taking in general. Because aggressive banks discount the future more highly (that is, they anticipate that they may no longer be solvent at the time a run on their deposits occurs), they hold less precautionary reserves and rely more on the LOLR facility. At the same time, if central bank reserves are limited and rationed among all banks, conservative banks increase their reserve holdings to avoid being rationed. It follows that, the central bank's reserves, when binding, will largely be used to support risky banks. In turn, by holding fewer reserves, risky banks will face lower intermediation costs than conservative banks and, hence, will be able to compete unfairly with conservative banks. Thus, in the limit, a reliable dollar LOLR funded in a large stock of liquid reserves at the central bank may lead to a more risky banking sector.

\section{Policy Implications}

Eliminating the provision of dollar LOLR under systemic liquidity crises would thus be desirable in that it would reduce the scope for distortions and induce banks to demand levels of dollar liquidity that are closer to the optimum. However, a dollar LOLR plays a useful role in resolving idiosyncratic liquidity crises and limiting contagion risk. Due to the central bank's privileged position (seniority status in liquidation claims and privileged information on the banks' financial situation) and its capacity to overcome coordination failures (in cases where it is optimal for the banking system as a whole to support a bank in difficulty but no bank can do it in isolation), a central bank LOLR that recycles dollar liquidity from liquidity rich banks to liquidity poor banks can improve on the functioning of the interbank market. ${ }^{20}$

when a particular bank cannot mobilize sufficient financing from other banks due to exposure limits.

${ }^{19}$ Unless the central bank can immediately "fiscalize" this cost by shifting it to the treasury, this may undermine its capacity to conduct monetary policy. See Ize (2005).

${ }^{20}$ See Freixas, Parigi, and Rochet (2004) for a recent review of the theoretical justification behind central bank LOLR. 
At the same time, by pooling reserves centrally and recycling liquidity, a dollar LOLR can greatly economize on (or obviate altogether) the need for international reserves. Thus, it enhances the capacity of individual banks to sustain a particularly large run on their deposits, thereby limiting contagion risks and increasing the resiliency of the banking system as a whole.

The distortionary impact of a dollar LOLR on the demand for bank reserves could be limited in principle by ensuring that its use is strictly restricted to idiosyncratic events. However, differentiating between purely idiosyncratic events and systemic runs is likely to be difficult (if not impossible) in practice. With contagion risk, idiosyncratic events can trigger systemic crises. At the same time, systemic factors can manifest themselves first in one or two banks.

Since a dollar LOLR facility serves a useful role and its use cannot be credibly restricted, the preferable second-best policy is to require that all banks hold minimum liquid dollar reserves in proportion to their liquid dollar liabilities. Introducing LAR will ensure that: (1) banks do not "free ride" on the central bank's LOLR and international reserves, thereby shifting the cost of the liquidity buffer to the public sector and undermining the central bank's solvency; and (2) weaker (or riskier) banks do not unduly benefit from the LOLR facility at the expense of the stronger, less risky banks, thereby making the financial system more brittle and vulnerable.

The LARs should be set such that they induce banks to hold socially optimal levels of liquidity. When liquidation costs are fully internalized by banks, the optimal LAR should match the liquidity levels banks would choose on their own in the absence of an LOLR facility. However, in the presence of externalities (that is, substantial additional bank liquidation costs that banks do not internalize), the LAR may need to be higher. To avoid any shift in the burden of the liquidity buffer to the public sector, the assets eligible for the LAR should be restricted to foreign assets that benefit from a deep, liquid market.

Once LARs are introduced, the central banks' dollar LOLR can be credibly limited to providing exceptional additional support to isolated banks that face very large liquidity shocks. Official international reserves to support such operations are only needed to the extent that central bank obligations to the banks supplying the liquidity may need to be partially backed by foreign reserves, particularly if they have a very short maturity. ${ }^{21}$

\footnotetext{
${ }^{21}$ If there is a market for short-term dollar treasury bills, the liquidity of that market may also need to be supported by a minimum backing of international reserves that allows the central bank to conduct repo operations against such instruments. However, the interest rate on these instruments should be allowed to rise under systemic crises, thereby limiting their liquidity and contributing to an interest rate defense by inducing other dollar rates (including on bank deposits) to rise.
} 


\section{Should Circuit Breakers Be InSTITUTIONALIZED?}

\section{A. Why Circuit Breakers?}

Given the cost of insurance (whether self-contracted or externally contracted), it is generally not optimal (or feasible) to fully back all deposits with liquid foreign assets. This raises the question of how to deal with too large (therefore, not optimally insurable) dollar liquidity runs. In this section we examine a novel mechanism that could complement LARs. What we have in mind is a scheme that limits in an organized and predictable way the convertibility of dollar deposits in the event of a pronounced run. As the scheme is intended to short-circuit the run at an early stage, we refer to it as a circuit breaker (CBR).

In most of the recent systemic bank panics in dollarized Latin American economies, governments were forced to take forceful measures at some stage to stop the runs. Ecuador, Argentina, and Uruguay are just three recent examples of dollarized economies where such measures became mechanisms of last resort. They represented desperate attempts to avoid a full collapse of the banking system and were designed in a rush in the midst of a crisis. In some cases, they took the form of a freeze on part or all of the deposits in the banking system, in others a forced restructuring of time deposits. In a few cases, a "corralito" was created, which meant that depositors maintained access to their funds but only if they remained in the (local) banking system (see Box 3$).^{22}$

However such measures (which were also in the nature of circuit breakers) were typically brought in at a late stage of the crisis, once the banks had exhausted their liquid reserves and the central banks had used a significant amount of international reserves, emulating a lender of last resort in the foreign currency. Moreover, their design was largely improvised at the spur of the moment, and their introduction implied a significant change in the rules of the game (including legally sanctioned contractual clauses) as they were not part of the regulatory framework at the time of the crises. Thus, the measures typically created large uncertainties at the time of their introduction, compounding those already inherent to the crisis. In addition, they gave rise in the months and years after the crisis to endless litigation, forcing some of these measures eventually to be reversed in the courts or resulting in costly fiscal outlays to settle the claims.

Instead, a CBR could be made an integral part of the regulatory framework and tied in with bank resolution procedures. The explicit adoption of a system of CBRs that are clearly prespecified has a number of important advantages. First, it helps depositors know the rules of the game in advance, and limits the scope for ex-post legal action against abuses on property rights. Second, it puts in place the market incentives that are needed for risks to be fully

\footnotetext{
${ }^{22}$ Some of the issues in this section are also discussed in Ingves and Moretti (2003), and Gulde et al. (2004).
} 


\section{Box 3: Introducing CBR-Type Measures Under Crises}

In deposit freezes, depositors lost access to the deposits included in the freeze and did not know how and when they would regain access (no clear mechanism or date were provided in that regard). Nor did depositors know the interest rate earned by the frozen deposits during the freeze. In most cases, the freeze was introduced as a temporary measure until a longer-term solution could be found.

Compulsory reprogrammings of selected deposits provided a preferable alternative in that depositors receive a new financial instrument from the bank with a known maturity, which could be securitized as a $C D$ or medium-term note, to be traded in the secondary and repo markets increasing its liquidity for cash-strapped depositors. However, the difference between the two is ultimately moot: if the conditions that led to the freeze are not reverted in the short run, it should eventually evolve into a full reprogramming.

The Argentine "corralito" (or fence) in principle had the advantage that it allowed depositors to maintain full access to their funds as long as they remained within the (local) banking system. Agents could issue checks and transfer funds between bank accounts, from one bank to another, from peso to dollars, and from time to sight deposits. However, they could not withdraw cash and their transfers abroad were restricted to commercial account transactions (capital controls were introduced).

The corralito, however, had a number of crucial drawbacks. First, it did not prevent the further dollarization of bank deposits (as agents anticipated a large devaluation). This deepened banks' currency mismatch, as banks were unable to adjust the currency denomination of their loans. In addition, it worsened flight to quality, as nothing prevented runs on the weakest individual banks. The central bank was therefore pressed into providing extensive lending of last resort. Individual bank failures happened in any event, thereby reinforcing the panic.

In addition, and most important, the corralito failed to shield the real side of the economy from the crisis. It ultimately affected the payments system, as a large part of the transactions were conducted in cash, which agents started to hoard and therefore became increasingly scarce. Figure 1 illustrates this point, showing the price of liquidity in Argentina 2002, as measured by the cash discount of checks in the informal market. This problem was compounded by the fact that, because the corralito allowed depositors to shift across currency and deposit type, it defeated the objective of isolating typically stable transactional peso deposits from declining dollar saving deposits.

Figure 1. Liquidity Premium

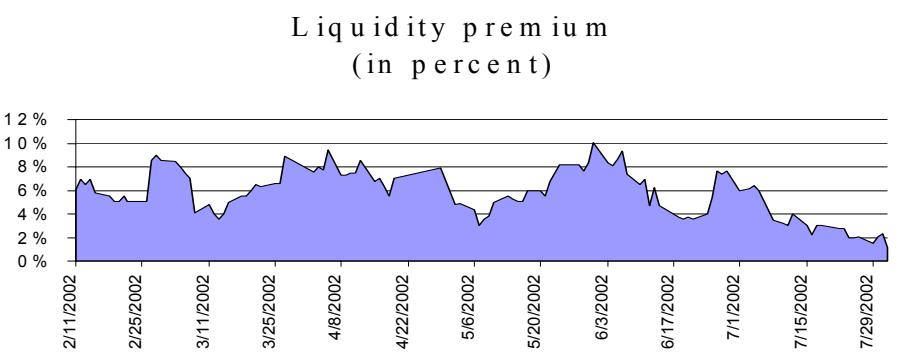

Source: Central Bank of Argentina. 
internalized and for the "most suitable players" to have a comparative advantage in banking intermediation, thereby limiting the vulnerability of the banking system. Finally, if the circuit breakers are well designed, they can reduce the cost of a crisis by ensuring that the payment system continues to function, banks remain open, and scarce dollar liquidity is allocated to its best use.

Governments have been so far reluctant to introduce CBRs during "tranquil" times, as part of the "standard" prudential regulatory framework partly out of concern that they could "scare away" depositors, thereby reducing the overall level of financial intermediation. However, there are some historical precedents for the use of CBRs during the free banking era that suggest they were well accepted by the public and ended up serving a useful purpose (see Box 4).

Chile provides a more recent illustration of a bank resolution mechanism which is rather similar to a CBR and which has been in place since after the 1982 banking crisis (see Box 5). Although admittedly aimed at idiosyncratic risk rather than systemic risk, and so far untested, this mechanism has not given rise to any substantial concern by banks' customers.

Indeed, one can also make a parallel between the attitude of emerging markets countries about the use of CBRs in the banking system and the adoption of collective action clauses (CACs) in sovereign debt markets. Until recently, most countries were reluctant to include the CAC in their legal documents because they feared that investors would react negatively and would require a higher interest rate on their bonds if they were issued with a clause that would make it easier for the country to restructure the debt. However, recent emerging market issues including CACs (e.g., Mexico, Brazil, or Uruguay) were not visibly penalized by the markets, suggesting that the concerns that countries had about including the clause in the bonds may have been largely unjustified.

There are reasons to expect that something similar may occur with the introduction of CBRs. On the one hand, if runs are triggered by the anticipation of inevitable bank losses, the presence of the CBR should not significantly affect the likelihood of the run. However, if liquidity crises are purely self-fulfilling and fueled by the memory of previous bank-run episodes, the CBR should be viewed as a desirable mechanism to help prevent banking panics and ensure a more stable banking environment—much in the same way as CACs are viewed by their advocates as a way of reducing the sunk cost of protracted debt crises.

\section{B. Which Deposits Should Be Subjected to the CBR?}

In considering which deposits should be subjected to the CBR, there are two key questions one needs to address: (1) what type and maturity of deposits (transactions, savings, or term deposits; short-term or long-term), and (2) which currency? 


\section{Box 4. CBRs and Suspension of Convertibility in the Free Banking Era}

The notion of circuit breakers resembles the suspension of convertibility (an option clause) that was included in bank contracts in Scotland and other European countries during the free banking era (in the eighteen and nineteenth centuries), and in the United States during the national banking period (1863-1914).

The option clause in Europe was introduced at a time when commercial banks issued most of the currency and notes in circulation, and when these notes could be redeemed at par for hard currency. The clause was designed to allow banks to "defer the redemption of their notes provided they pay interest for the period of deferment" (Shah, 1997). In addition in the notes there was a printed statement that promised to pay a higher interest rate for the period of deferment.

There is little evidence regarding how widely the option clause was used in practice and about its effectiveness. Nevertheless, Shah (1997) states that the Bank of Scotland introduced an option clause in 1730 in its notes and that it remained in place until 1765, when it was outlawed.

The other useful experience was occasions when convertibility of notes was suspended in the United States since the Civil War. Calomiris and Gorton (1991) describe seven major episodes when there was a suspension of convertibility of notes $(1873,1893,1907$, and 1914) during the National Banking Era. The suspension of convertibility was perceived as an effective way to deal with bank panics, as it minimized the cost to depositors and avoided a large amount of bank failures. Calomiris and Gorton estimate that the worse loss to depositors during the National Banking Era was 2.1 cents per dollar of deposits while the worse case in terms of banks failing was 1.28 percent during the Panic of 1893 (p. 114).

Dwyer and Hasan (1999) provide additional evidence in favor of using some form of CBR. They compare the impact of the 1861 bank panic in Wisconsin and Illinois and find that while 87 percent of banks in Illinois finally closed, around 44 percent of the banks closed in Wisconsin. They argue that the introduction of the suspension of payments in Wisconsin is the main reason that explains the better performance of the banks in Wisconsin during the panics. In addition, they provide evidence indicating that the suspension of payments decreased noteholders' losses by about 20 percent.

Let us address the second question first. Should the CBR be limited to dollar deposits, or should it be extended to include peso deposits? There are three ways to approach this issue, which are, in turn, intimately related to the expected monetary policy reaction to the run. The first one clearly differentiates pesos from dollars: in the event of a crisis (if not before), the monetary authorities will protect the peso by letting the exchange rate float. The second approach is to treat pesos and dollars in exactly the same way: the regulatory framework is currency-blind. The third approach is an intermediate one: pesos and dollars are subjected to different regulations but the central bank will maintain at all times (through its international reserve holdings, monetary policy, and/or peso LOLR) the full convertibility of peso deposits into cash or dollars. 


\section{Box 5. A More Recent Example of Pre-Programmed CBR: The Chilean "Narrow Bank" Safety Net}

Sight deposits (and term deposits of less than 30 days or whose term to maturity is less than 10 days) are fully guaranteed by the Central Bank of Chile (BCCh), which protects itself from potential losses by requiring that banks hold liquid assets (in the form of central bank debt) against sight deposits in excess of 2.5 times their capital. In addition, if the guarantee were triggered, the BCCh would become the most senior claimant on the bank's assets.

When a bank is unable to meet its commitments (including as regards its liquid asset requirement) or severe solvency or managerial shortfalls emerge (as defined in the banking law), the bank's non-sight liabilities are frozen while sight deposits remain fully accessible; they are "decoupled" from the rest of the bank together with the corresponding liquid assets plus the BCCh guarantee. This protects the payments system, mitigates the contagion risk of a bank closure, and provides breathing room for an efficient resolution of the non-narrow part of the bank.

The risk of an unwarranted, last minute expansion of the guarantee is limited by a five-day advance notice required by banks for transferring term deposits into sight deposits. The bank resolution system is conditioned to (and shaped by) a creditor agreement ratified by the majority (in terms of claims) of the bank's non-sight creditors (and the Superintendency of Banks and Financial Institutions). When an agreement cannot be reached, outright liquidation on the entire non-narrow bank is the only possible outcome.

\section{Source: Chile FSSA.}

By clearly signaling the differences between pesos and dollars, the first option (letting the exchange rate go) is fully consistent with a medium-term de-dollarization strategy. Moreover, it limits the need for foreign reserves. However, as already noted, a large exchange rate depreciation (needed to keep the pesos in place) will probably undermine the solvency of the banking system in a highly dollarized economy, in turn exacerbating the scope for preventive runs and complicating crisis management. Moreover, unless ways can be found to protect the solvency of the peso component of banks' balance sheets (more on this below), the dollar will ultimately carry the peso with it into the abyss - in which case limiting CBRs to dollars may fail to stabilize peso deposits.

The second option is consistent with a currency board, where the local currency is legally convertible to a foreign currency at a fixed exchange rate. Its main drawback, as exemplified in the recent Argentine experience, is that it requires very large international reserves. Unless this is the case, it may not be credible and may ultimately unravel. If so, currency blindness leads to the worst of all worlds in which dollarization is promoted and all hell breaks loose in the event of a crisis. 
The third option is, in principle, viable for highly dollarized countries that do not envisage a radical change of monetary regime and do not see de-dollarization as a viable short-term goal, but that wish nonetheless to keep all their options open. In such cases, provided the CBR ensures that dollar deposits are not converted into peso deposits as a way to siphon off scarce dollar reserves (peso deposits could be paid off with peso LOLR liquidity and later converted back into actual dollars), the limited size of peso deposits allows them to be credibly backed and the exchange rate maintained. The regulatory framework can thus be currency-specific. The pesos do not need to be subjected to LARs or CBRs. Instead, the central bank can provide the necessary support through conventional means.

As regards the type of deposits subjected to the CBR, the aim should be to maintain access to transaction deposits (checking and savings accounts) while restricting access to the most liquid savings instruments that can be withdrawn at short notice. A natural choice is to apply CBRs only to time deposits, while ensuring the full convertibility of transactional deposits (into cash or dollars). ${ }^{23}$

Note that this option would call for differentiated LARs on dollar deposits. Banks should hold enough liquid assets to back dollar sight deposits, much as in a narrow banking system. However, in the case of dollar term deposits, the backing could be reduced and banks would rely instead on the CBR to cope with substantial withdrawals. ${ }^{24}$ More generally, banks (and their clients) could be offered a choice between instruments not subjected to CBRs but with high LARs, and instruments subjected to CBRs but benefiting from low LARs. ${ }^{25}$ At any rate, the substitutability between LARs and CBRs suggests that the two should be determined jointly.

${ }^{23}$ The main advantage of differentiating between time and sight deposits is that to the extent that agents maintain access to their transactional balances, it minimizes the impact on the payment system. While this is not a perfect solution, as some of the time deposits might be a temporary store of value of transactional balances, it is probably the best available option at the time of a crisis.

${ }^{24}$ Whether the LAR needs to be close to, or exactly equal to, 100 percent of deposits is debatable. What is important is that the level should be significantly higher than encountered in real life cases.

${ }^{25}$ To promote the development of long maturity instruments, their LARs could be reduced. This would require, however, that long maturity instruments be issued in the form of CDs that cannot be redeemed ahead of time but can be traded in the stock exchange. Bolivia's experience with over two-year maturity savings instruments is an interesting precedent in this regard. 


\section{Who Should "Pull the Trigger" and When?}

There are two key policy issues as regards the activation of the CBR: (1) the point at which the CBR should be activated, and (2) whether it should be activated centrally (on the basis of the overall liquidity of the banking system) or based on bank-specific liquidity indicators. ${ }^{26}$ There are (at least) four possible solutions to the first issue. The first option consists of having a purely systemic trigger that sets off when systemic liquidity hits a certain threshold and applies to all banks. While it has the advantage that it brings the run to an early halt across-the-board, it suffers from two crucial shortcomings. First, it is imposed on banks that might not need the CBR, because they have enough liquidity or have access to funding from abroad, through their parents or through market arrangements. Thus, a one-size-fits-all solution has perverse incentive effects: it penalizes the more conservative local banks that manage their liquidity better, and erases the natural competitive advantage in dollarized environments of the large, reputable international banks (giving them instead the legal and "market" backing - hence the option - to shy away from their losses and leave the country in the event of a crisis). ${ }^{27}$ Second, it is bound to be questionable on legal grounds, in the absence of a verifiable indicator of the systemic nature of the run - defeating one of the key goals of the CBR system, namely, the limitation of the fiscal losses associated with a run, because of litigation costs that inhibit timely action in the context of a crisis, or burden taxpayers once the crisis is behind.

Solution number two sits at the other extreme. It relies on a purely idiosyncratic trigger that automatically sets off when any individual bank runs out of liquidity. The main problem with this option is that it removes the disciplining benefit on banks' management and lending policies of being exposed to the threat of a run, motivated by concerns from depositors about the solvency of the bank. ${ }^{28}$ By discouraging depositors from investing in banking systems with CBRs and/or raising the cost of funds for such systems, this could make the introduction of CBRs politically more difficult.

Solution number three is a middle-of-the-road solution. To become activated, the CBR would require both that a bank's liquidity fall below a certain threshold and that the supervisors consent to the activation of the CBR, on the grounds that the underlying cause of the run is systemic rather than idiosyncratic. By ensuring that banks do not take advantage of the CBR

\footnotetext{
${ }^{26}$ A related issue is who should be legally responsible for enforcing the CBRs (a thorny question given the pressures that supervisory authorities face in the midst of a crisis).

${ }^{27}$ In the case of branches of foreign banks, the legal backing of the branches' deposits by the parent institution is immediately made null and void by a forceful reprogramming of deposits.

${ }^{28}$ See Diamond and Rajan (2001).
} 
to pursue excessively risky policies, this would limit the scope for moral hazard. This solution, however, shares with the first option the drawback that it introduces a scope for discretionality in the definition of systemic crises. In particular, supervisors might be reluctant to consent to using the CBR on the grounds that doing so might expand the run to other banks - as well as triggering risks of litigation. Indeed, once the CBR is activated in one bank, risks of contagion and domino effects will rise. ${ }^{29}$ Thus, this solution is likely to lead to a bias against the activation of the CBR, limiting their usefulness.

Solution number four is a milder, CBR-like, option that retains the liquidity of transaction deposits (based on a Chilean-type deposit insurance) while allowing the rest of the bank to be "temporarily closed." If able to fulfill its prudential requirements, the bank would be reopened once the crisis has subsided; it would otherwise be liquidated. During the "suspension" period, arrangements would be needed to ensure proper management of the bank's assets. This option would also involve supervisory discretion. However, the supervisor's prompt consent would be more likely here than under option three, as it would go in a positive direction (postponing the liquidation of a closed bank, rather than restructuring the deposits of an open bank). Indeed, by stressing deposit protection, this option could be easier to sell.

As to what should determine the trigger for the CBR, the discussion above clearly favors non-discretionary triggers in order to avoid costly delays due to agency problems. On the one hand, banks are likely to delay the introduction of the CBR and "gamble for resurrection." However, the longer the decision is postponed the larger the amount of liquid reserves that the financial system would lose. ${ }^{30}$ As discussed above, leaving the decision to the central

${ }^{29}$ The literature on contagion in bank runs suggests that once a specific type of bank has failed (cooperative, wholesale, regional, etc), the run quickly spreads to other similar banks. To be sure, the triggering of a CBR in a context in which there is "systemic nervousness" is likely to quickly lead to a segmentation of the banks into two groups: those that have the support (and credibility) to continue doing business as usual, and those that do not. While this may look harsh to the banks that are unable to withstand the run, it reflects the risks of intermediating in dollars and the comparative advantages of different banks in a dollarized environment. By better internalizing risks and ensuring a more efficient competition in the market place, this should ultimately benefit the peso (as an independent currency), promote the depth of financial intermediation, and increase its resilience.

${ }^{30}$ The bank will evaluate this tradeoff from its own cost-benefit analysis perspective. If it perceives problems in other banks, it will most likely try to protect its own liquidity in order to remain stronger in case of a run, and would not internalize any possible negative externality on the banking system. If it faces a run it will most likely try to postpone the decision to introduce the circuit breakers, in fact doing just the opposite; take a more aggressive bet in order to maintain the bank operational, undertake a fire sale of its best and most liquid assets, and try to get more assistance from the central bank in order to "gamble for resurrection." 
bank is also problematic. In either case, allowing for discretion would enhance the scope for ex post battles in the courts - and, for the same reason, ex ante hesitation.

Thus, the CBRs should be automatic and fully determined by market forces, in the form of transparent, legally uncontestable criteria. A natural mechanism would entail linking the trigger to the failure of the bank to comply with a minimum level of liquidity, so that LARs assigned to back non-CBR deposits are not compromised. Consider the case of a CBR on dollar time deposits. As the latter leave the bank, or move to sight —or peso-deposits to elude the CBR in anticipation of a run, the stock of LARs associated with dollar time deposits will start to decline. At the beginning, the bank can cushion part of the decline using excess liquidity elsewhere, or borrowing dollars from the market. Ultimately, however, its liquidity will fall below the level needed to fully back transaction deposits, and the bank would be forced to introduce the CBR.

\section{What Happens the Day After?}

The effectiveness of CBRs in stopping (or preventing) runs and restoring confidence in the banking system ultimately depends on whether their introduction (before or after the fact) creates expectations of forthcoming losses on the restructured deposits. Indeed, if expectations of forthcoming losses are widespread, the existence of CBRs is likely to encourage preventive runs. Whether this will be the case largely depends on the broader prudential framework and on what happens after the CBRs have been introduced.

Clearly, a well-capitalized banking system (where the risks of dollar loans to non-dollar earners have been adequately internalized) will be better able to absorb losses on its dollar loans, thereby limiting both potential losses to depositors and the potential adverse impact of the CBR. Requiring banks to hold sufficient capital against any shock might be too expensive, however. Thus, there might be instances where some losses (or the possibility of incurring some losses) are unavoidable.

In this context, some key issues need to be addressed. First, the "rules of the game" that define what happens after deposits have been restructured should be well specified and as transparent as possible. In particular, the time frame of the restructuring and what happens if the bank's liquidity problems are not resolved within the restructuring period need to be well specified. In all cases, there should be a well-defined, efficient banking resolution procedure that minimizes the loss in the value of the deposits, should the bank be ultimately unable to face its obligations (for reasons of solvency or liquidity).

For dollarized economies, a specific issue that arises in this context is how to limit the scope for cross-currency risk contamination and maintain the confidence of the public in the peso bank (so as to maintain it open and running) when dollar liabilities have been restructured. One option, which is close in spirit to the Chilean scheme, is to give peso depositors an official guarantee, backed by preferential claims on the residual value of the bank-which in practice amounts to granting seniority to transaction deposits. 
Another option is to limit the bank's liability on its dollar losses to its dollar capital, e.g., should the dollar bank lose its capital, the capital of the peso bank is not called up to the rescue. In the limit, a case can be made for fully "de-coupling" the peso and dollar components of the bank's balance sheet as soon as CBRs are introduced (much as, in the case of the Chilean safety net scheme, the transaction-based "narrow bank" is de-coupled from the rest of the bank). This would require that the dollar assets that are the counterpart of the dollar deposits and the dollar capital that backs these assets be transferred to a separate shadow balance sheet (which could eventually be transformed into a trust fund if the bank is unable to re-incorporate it within its broader balance sheet), virtually dividing the institution into a peso and a dollar bank. This separation would immediately reduce incentives for dollarization. ${ }^{31}$ The legal underpinnings of this proposal could be complicated, however.

\section{Conclusions}

This paper tackled a question that clearly has important policy implications but has received little attention in academic circles: how should scarce dollar systemic liquidity be managed in a highly dollarized environment? The paper looked at three interrelated facets of this issue: (1) Should liquidity be held or can it be borrowed? (2) When held, should it be centralized or decentralized (e.g., held by the central bank or by individual commercial banks)? (3) When demands on this liquidity become excessive, should they be stopped in their tracks through the use of pre-wired, transparent, circuit breakers?

The previous discussion drew a number of relevant—albeit preliminary_conclusions:

1. The current menu of liquidity insurance options is mostly limited to forms of selfinsurance (e.g., holding your own liquidity). While market-based (or official) insurance has in principle many advantages, getting the right combination of size, cost, and guaranteed access seems to be beyond what markets (or IFIs) can presently offer.

2. Given the need for self-insurance, accumulating reserves centrally induces moral hazard as banks, particularly weaker ones, free ride on the central bank and hold a suboptimally low level of dollar liquidity. In addition to penalizing the more conservative banks, centralized reserve holdings end up subsidizing the dollar at the expense of the peso.

3. Decentralized LARs are thus generally preferable. Once introduced, however, the central bank may wish to also maintain some international reserves and a dollar LOLR capacity to further limit the scope for runs on individual banks.

4. The optimal level of LAR — and, in particular, the associated cost in terms of reduced loanable funds and wider intermediation margins — can be reduced by complementing

${ }^{31}$ Broda and Levy Yeyati (2003b). 
them with circuit breakers (CBRs), namely, the automatic and early suspension of convertibility of (dollar) deposits to prevent exhausting the dollar liquidity and compromising the payments system.

5. To be successful (e.g., to be stabilizing rather than destabilizing), CBRs should be accompanied by a sound and transparent prudential and bank resolution framework that limits the scope for losses to depositors.

6. The introduction of CBRs is likely to be smoother if the emphasis is put on deposit protection and efficient bank closures instead of deposit restructurings. 


\section{A Model OF LENDER OF LAST ReSORT (LOLR) AND BANK DEMAND FOR DOLLAR LIQUIDITY}

\section{A. The Basic Setting}

Suppose there are dollar banks offering dollar deposits and investing in dollar loans or dollar reserves abroad, and peso banks offering peso deposits and investing in peso loans or peso central bank bonds. To begin with, suppose all dollar banks and all peso banks have identical assets and risk preferences.

In deciding how much liquidity to hold, dollar banks compare the carrying cost of their liquidity to the cost associated with being unable to meet the demand for deposit withdrawals. The carrying cost of dollar liquidity equals the spread $s_{D}=r_{D}-r_{D}^{*}$ where $r_{D}$ is the local dollar lending rate, and $r_{D}^{*}$ is the world rate of return on liquid dollar assets.

Similarly for peso banks, the carrying cost of liquidity is the spread $s_{P}=r_{P}-r_{P}^{*}$ where $r_{P}$ is the peso lending rate and $r_{P}^{*}$ is the yield of central bank peso bonds. Assuming interest rate parity, $r_{D}=r_{P}$, and a positive country and currency premium, $\varphi=r_{P}^{*}-r_{D}^{*}>0$, it follows that: $s_{D}-s_{P}=r_{P}^{*}-r_{D}^{*}=\varphi$.

Let $P(x)$ be the cumulative probability of facing a systemic deposit run (uniform over all banks and currencies) of up to size $x$, where $x \in[0,1]$ is the proportion of the bank's deposits. $P(x)$ is assumed to be monotonically increasing and convex over the range $[0,1]$, so that $P^{\prime \prime}(x)<0$ over the range (runs of size $x$ become less and less likely as $x$ increases). For simplicity, we assume $P(x)$ exogenous and identical for peso and dollar banks. The cost of falling short of liquidity is the loss of value resulting from the firesale of loans, which is defined (per value of loan) as $\mu$, and is assumed to be the same for peso and dollar loans.

\section{B. The Case of No LOLR}

In the absence of a LOLR, banks hold liquid reserves, $l$, such that they can meet deposit withdrawals up to the point where the carrying cost of a marginal unit of reserves equals the expected benefit of being able to meet the marginal demand for deposits (thereby avoiding the marginal cost of fire sales). Thus:

$$
s_{i}=\mu P^{\prime}\left(l_{i}\right), i=P, D
$$

or:

$$
l_{i}=P^{\prime-1}\left(\frac{S_{i}}{\mu}\right), i=P, D
$$


where, in view of the convexity of $P, \frac{\partial P^{\prime-1}(u)}{\partial u}<0$.

\section{The Case with LOLR}

To ensure that the LOLR is only used as a last resort, its rate must be a penalty rate $R_{i}=r_{i}+\sigma_{i}$, where $\sigma_{i}>0, i=P, D$. At the same time, for the facility to be used: $R_{i}<\mu$. If access to LOLR is unlimited (i.e., as long as the stock of official reserves is not binding), banks will limit their demand for liquidity such that the carrying cost of the marginal reserve equals the expected cost of accessing the LOLR facility:

$$
S_{i}=R_{i} P^{\prime}\left(\hat{l}_{i}\right)
$$

so that the demand for bank reserves now becomes:

$$
\hat{l}_{i}=P^{\prime-1}\left(\frac{s_{i}}{R_{i}}\right)
$$

Since $R_{i}<\mu$, banks' demand for liquid reserves is now lower $\left(\hat{l}_{i}<l_{i}\right)$ and declines as $R_{i}$ increases. Provided the cost of using the LOLR facility is sufficiently high, $R_{i}>s_{i} / P^{\prime}(0)$, it pays for banks to keep a minimum cushion of reserves to accommodate deposit withdrawals within a limited range where runs are more likely. For larger, less likely runs, banks are better off counting on the central bank to bail them out.

In the case of a dollar LOLR, the carrying cost of reserves should equal $s_{D}$, as before. Yet, the expected revenues from holding a marginal unit of official reserves are $R_{D} P^{\prime}(x)$ for $x \in\left[\hat{l}_{D}, \hat{l}_{D}+N\right]$. From (3), it is clear that: $s_{D}>R_{D} P^{\prime}(x)$ in that range. Thus, the central bank will be making losses.

\section{Differentiated Banks}

Suppose there are two types of dollar banks. Aggressive banks invest in riskier projects and face a positive probability of becoming insolvent at some time before the deposit run. If $p$ is the probability that the bank will still be solvent at the time of the run, ${ }^{32} \alpha<1$ is the fraction of the spread associated with the cost of carrying the reserves during the time the bank remains solvent, and $s_{D}^{a}$ and $s_{D}^{c}$ are the spreads faced by aggressive banks and conservative banks, with $s_{D}^{a}>s_{D}^{c}$ reflecting higher risk, the demand for liquidity by aggressive banks may be expressed as:

$32 p$ should be a function of $x$, with $p^{\prime}(x)<0$, reflecting the fact that larger runs will occur more infrequently. But this does not change the nature of the conclusions. 


$$
s_{D}^{a}[p+\alpha(1-p)]=R_{i} P^{\prime}\left(l_{D}^{a}\right) p
$$

or:

$$
s_{D}^{a} \frac{p+\alpha(1-p)}{p}=R_{D} P^{\prime}\left(l_{D}^{a}\right)
$$

Since $s_{D}^{a} \frac{p+\alpha(1-p)}{p}>s_{D}^{c}, l_{D}^{a}<l_{D}^{c}$ i.e., aggressive banks hold fewer reserves than conservative banks. Hence, they will make a disproportionate use of the LOLR facility. In turn, if central bank reserves are limited and rationed among all banks, conservative banks will increase their reserve holdings to avoid being rationed. Thus, for $x \in\left[l_{D}^{a}, l_{D}^{c}\right]$, the central bank's reserves, when binding, will only be used to support risky banks. 


\section{REFERENCES}

Broda, C., and E. Levy Yeyati, 2003a, "Dollarization and the Lender of Last Resort," in Dollarization: Debates and Policy Alternatives, ed. by E. Levy Yeyati and F. Sturzenegger (Cambridge, Massachusetts: MIT Press).

,2003b, "Endogenous Deposit Dollarization," Staff Report 160 (New York:

Federal Reserve Bank of New York), also forthcoming in Journal of Money, Credit and Banking.

Calvo, G., 1988, "Servicing the Public Debt: The Role of Expectations," American Economic Review, Vol. 78, pp. 647-61.

Cole, H., and T. Kehoe, 1996, “A Self-fulfilling Model of Mexico's 1994-1995 Debt Crisis," Journal of International Economics, Vol. 41, pp. 309-30.

Caballero, R., S. Panageas, 2004, "Contingent Reserves Management: An Applied Framework,” NBER Working Paper No. 10786 (Cambridge, Massachusetts: National Bureau of Economic Research).

Calomiris, C., and G. Gorton, 1991, "The Origin of Banking Panics: Models, Facts, and Bank Regulation," in Financial Markets and Financial Crisis, ed. by Glenn Hubbard (Chicago: The Chicago University Press), pp. 109-73.

Chang, R., and A. Velasco, 1998, "Financial Crises in Emerging Markets," NBER Working Paper No. 6606 (Cambridge, Massachusetts: National Bureau of Economic Research).

Cordella, T., and E. Levy Yeyati, 2005, “A (New) Country Insurance Facility,” IMF Working Paper No. 05/23 (Washington: International Monetary Fund).

Cowan, T., and R. Kroszner, 1989, "Scottish Free Banking before 1845: A Model for Laissez-Faire?" Journal of Money, Credit, and Banking, Vol. 21, No. 2 (May).

Diamond, D., and P. Dybvig, 1983, "Bank Runs, Deposit Insurance, and Liquidity,” Journal of Political Economy, Vol. 91, No. 3, pp. 401-19.

, and R. Rajan, 2001, "Liquidity Risk, Liquidity Creation, and Financial Fragility: A Theory of Banking," Journal of Political Economy, Vol. 109, No. 2, pp. 287-327.

Dwyer, G., and I. Hasan, 1999, "Suspension of Payments, Bank Failures and the Nonbank Public's Losses," unpublished.

Freixas, X., B. Parigi, and J.C. Rochet, 2003, “The Lender of Last Resort: A $21^{\text {st }}$ Century Approach,” ECB Working Paper 298 (Frankfurt: European Central Bank). 
Golfajn, I. and R. Valdés, 1997, "Balance of Payments Crises and Capital Flows: The Role of Liquidity," Central Bank of Chile Working Paper No. 11 (Santiago).

Gulde, A.M., D. Hoelscher, A. Ize, D. Marston, and G. De Nicoló, 2004, "Financial Stability in Dollarized Economies," IMF Occasional Paper 230 (Washington: International Monetary Fund).

Ingves, S., and M. Moretti, 2003, "Banking Failures in Countries Dependent on a Foreign Currency," Paper presented at the workshop on "Individual Failures of Large Banks: How To Avoid Systemic Crises?” Buenos Aires, unpublished.

Ize, A., 2005, “Capitalizing Central Banks: A Net Worth Approach,” forthcoming in Staff Papers, International Monetary Fund.

, and G. Ortiz, 1987, "Fiscal Rigidities, Public Debt, and Capital Flight," Staff Papers, International Monetary Fund, Vol. 23, No. 2, pp. 311-32.

Kaminski, G., and C. Reinhart, 1999, "The Twin Crises: The Causes of Banking and Balance-of-Payments Problems," American Economic Review, Vol. 3, pp. 473-500.

Levy Yeyati, E. , S. Martínez Pería, and S. Schmukler, 2004, "Market Discipline in Emerging Economies: Beyond Bank Fundamentals," in Market Discipline across Countries and Industries, ed. by W. Hunter, G. Kaufman, C. Borio, and K. Tsatsaronis, (Cambridge, Massachusetts: MIT Press).

Shah, P., 1997, "The Option Clause in Free-Banking, Theory and Practice: A Reappraisal," Review of Austrian Economics, Vol. 10, No. 2, pp. 1-25.

Zettelmeyer, J., 2000, "Can Official Crisis Lending be Counterproductive in the Short Run?" Economic Notes, Vol. 29, No. 1, pp. 13-29. 